\title{
The Cost and Benefice of Multiple Mating in Desert Locust Schistocerca gregaria
}

\section{Dushimirimana Severin ${ }^{1 *}$

\author{
Article History \\ Received: 13.02 .2021 \\ Accepted: 27.02 .2023 \\ Published: 12.03 .2021 \\ Journal homepage:
} \\ http://www.easpublisher.com}

Ecole Normale Supérieure du Burundi, Boulevard Mwezi Gisabo Campus Kigobe PoBox 6983 Bujumbura-Burundi

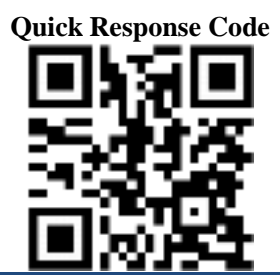

\begin{abstract}
A better understanding the evolution of female desert locust multiple mating role is key to understand locust phase polyphenism and locust outbreaks. In this study, we analyse the cost and the benefice of multiple mating in desert locust Schistocerca gregaria. We demonstrated that female desert locust fecundity and fertility is not affected by multiple copulation. We found that multiple mating affect female lifespan where we observed an increase in mortality in females mated with more than one male comparatively to females mated with a single male. We found that survival of offspring from females mated with two, three, four males remain higher and our results show that about $90 \%$ of larvae reach at imago stage while only $74 \%$ of larvae reach at imago stage in females mated with single male. The sense of this result could be male-derived nutrients which are incorporated in female eggs thereafter in hatchlings. Multiple mating in $S$. gregaria acts as hormonal factor which controlling egg size and eggs contain which acted on offspring condition with a really impact on survival.

Keywords: desert locust, multiple mating, Schistocerca gregaria, offspring.
\end{abstract}

Copyright (C) 2021 The Author(s): This is an open-access article distributed under the terms of the Creative Commons Attribution 4.0 International License (CC BY-NC 4.0) which permits unrestricted use, distribution, and reproduction in any medium for non-commercial use provided the original author and source are credited.

\section{INTRODUCTION}

For millennia, farmers have been confronted with swarms of locusts capable of spectacular migrations and which represent major threats to their crops. More than 1200 species of locusts are known in the world, of which 500 species have economic consequences in agriculture. Twenty species are among crop pests especially in Africa [1].

The main species are the desert locust (Schistocerca gregaria), the migratory locust (Locusta migratoria), the nomadic locust or red locust (Nomadacris septemfasciata), the tree locust (Anacridium melanorhodon), the Mato Grosso locust (Rhamatocerus schistocercoides) and the Brazilian locust (Chromacris speciosa) [2]. These species have a common characteristic: phase transformation from a solitary phase to a gregarious phase which is responsible for the invasion during which bands of larvaes evolve in swarms causing considerable damage. These species have also the possibility of presenting varied and reversible aspects according to living conditions. This polymorphism is essentially linked to the conditions of the social environment of each species [3]: in the presence or isolated from its congeners [4]. The main triggering factor is the density of individuals [5].
Among these species, our study focused on desert locust $S$. gregaria, a polyphagia specie which consumes its own weight of fresh food per day [6]. Normally solitary, these locusts from the Saharan and sub-Saharan regions reproduce when certain ecological and meteorological conditions are met $[7,8]$, to become gigantic swarms which attack all types of crops [9]. These swarms migrate to desert and semi-desert countries in Africa and Asia causing enormous economic consequences.

The females of S.gregaria have multiple mating with various males. The benefits for female of multiple mating in Orthoptera have been shown to have many functions as prevent the females from sperm depletion [10], increasing the rate of oviposition [1113] or provide material incorporated into eggs [14, 15]. However, until now, adaptive significance of polyandry is poorly understood in $S$. gregaria.

In their study on behavioural analysis of phase change, Simpson et al. [16] have concluded that female locusts can predict the probabilility that their offspring will emerge into a high-density population, and alter the development of their embryos accordingly through a gregarizing agent added to the foam that surrounds the eggs at laying. 
Recently, it was discovered that progeny characteristics such as hatchling body size and color are pre-determined in the ovaries of the mother in $S$. gregaria [17-19].

In desert locusts, it has been shown that males presence (with or without mating) increased female activity, which stimulates development and oogenesis $[20,21]$ and increases clutch size [22].

In this study, we analysed the cost and the benefice of multiple mating in desert locust $S$. gregaria. Concretely the effects of multiple mating on fecundity and fertility are analysed. Paternal and maternal investments of multiple mating are examined as females and offspring longevity.

\section{Materials ANd Methods Insect rearing}

Mass rearing of gregarious S. gregaria was conduct in cages (dimensions; 50X60X80 cm) containing 100 to 200 locusts per cage. Rearing temperatures were $35^{\circ} \mathrm{C} \pm 2{ }^{\circ} \mathrm{C}\left(12 \mathrm{~h}\right.$ day) and $28^{\circ} \mathrm{C} \pm$ $2{ }^{\circ} \mathrm{C}$ (12h night) with a relative humidity of $60 \%$. Locusts were fed on fresh cabbage leafs and rolled oats. Mature females and mature males were collected in cages few days before sexual maturation and separated by sex to ensure virgin status.

\section{Mating test}

Mature females were placed individually with mature males in experiment cage for mating. These cages were observed until the male disengaged his genitalia and males were then removed to prevent remating. To ensure that mated females were inseminated, only females that copulated for more than 1h (according to our previous results: Dushimirimana et al. [23] were taken. Among these females $(n=63)$ have been placed in cage to determine the number of eggs (fecundity) and the number of nymphs (fertility) for each female until the females died. Plastic cups filled with clean moist sand were placed in cages to collect egg pods. Egg pods collected were incubated at $30^{\circ} \mathrm{C}$. The once mated remaining females were marked with painting for the remating tests.

Marked mated female were placed with a new virgin male 24 hours after the first mating. After the second copulation, females were allowed to lay egg till death. Third and fourth rematings were conducted in the same way. A group of females $(n=47)$ was allowed to mate and stay with a group of four males. Fecundity and fertility were examined.

Polyandrous females, used in remating test, were monitored every day and dead individuals were counted for longevity. Survival of offspring produced by multiple mating or single mating was also determined until imaginal moult. Offspring were maintained in the same conditions of rearing as explained above and dead individuals were counted.

\section{RESULTS}

In our laboratory experiences, we tested the cost and the gain for a female $S$. gregaria to accept the mating with several males. Five treatments have been analysed during this survey: a female mated with only one male, two, three and four males. We also analysed a female remained with four males to test the influence of the presence of a male.

\section{Fecundity}

There is no significant difference in fecundity among females mated with single male or multiple mated. Indeed, during the first clutch, the mean fecundity is $66.5 \pm 12.6$ eggs in females mated with a single male, $63.8 \pm 9.6$ eggs in females mated with two males, $57 \pm 7.2$ eggs in females mated with three males, $62.8 \pm 11.1$ eggs in females mated with four males $63 \pm 6.5$ eggs in females with four males (One-way Analysis of Variance $\mathrm{P}=0.43$ ) Table 1.

In second clutch, the mean fecundity is $64 \pm 6.6$ eggs in females mated with a single male, $53 \pm 6.5$ eggs in females mated with two males, $61 \pm 10.5$ eggs in females mated with three males, $53 \pm 15.1$ eggs in females mated with four males $55.8 \pm 3.8$ eggs in females with four males ( One-way Analysis of Variance $\mathrm{P}=0.49$ ) Table 1.

In third clutch, the mean fecundity is $58.5 \pm$ 7.7eggs in females mated with a single male, $54.5 \pm 3.5$ eggs in females mated with two males, $56 \pm 2.8$ eggs in females mated with three males, $49 \pm 7$ eggs in females mated with four males $47.5 \pm 6.3$ eggs in females with four males ( One-way Analysis of Variance P $=0.38$ ) Table 1.

Table-1: Fecundity (Means of eggs laid)

\begin{tabular}{|l|l|l|l|l|}
\hline & Treatment & First clutch & Second clutch & third clutch \\
\hline \multirow{3}{*}{ Fecundity } & Female mated with a single male & $66.5 \pm 12.6$ & $64 \pm 6.6$ & $58.5 \pm 7.7$ \\
\cline { 2 - 5 } & Female mated with two males & $63.8 \pm 9.6$ & $53 \pm 6.5$ & $54.5 \pm 3.5$ \\
\cline { 2 - 5 } & Female mated with three males & $57 \pm 7.2$ & $61 \pm 10.5$ & $56 \pm 2.8$ \\
\cline { 2 - 5 } & Female mated with four males & $62.8 \pm 11.1$ & $53 \pm 15.1$ & $49 \pm 7$ \\
\cline { 2 - 5 } & Female \&4 males & $63 \pm 6.5$ & $55.8 \pm 3.8$ & $47.5 \pm 6.3$ \\
\hline One-way Analysis of Variance & $\mathrm{P}$ & 0.4301 & 0.4995 & 0.3871 \\
\hline
\end{tabular}




\section{Fertility}

In three clutches, we found also no significant difference among treatment (Table 2). There is no significant difference in fertility among females mated with single male or multiple mated. Indeed, during the first clutch, the fertility is $90.2 \pm 2.6$ larvae in females mated with a single male, $91.7 \pm 4.6$ larvae in females mated with two males, $88.6 \pm 5.2$ larvae in females mated with three males, $90.7 \pm 7.1$ larvae in females mated with four males $88.3 \pm 3.5$ larvae in females with four males (One-way Analysis of Variance $\mathrm{P}=0.78$ ) Table 2.

In second clutch, the mean fertility is $85.4 \pm 2.6$ larvae in females mated with a single male, $92.6 \pm 4.5$ larvae in females mated with two males, $88.9 \pm 10.5$ larvae in females mated with three males, $87.8 \pm 8.1$ larvae in females mated with four males $89.3 \pm 4.8$ larvae in females with four males ( One-way Analysis of Variance $\mathrm{P}=0.77$ ) Table 2.

In third clutch, the mean fertility is $80.2 \pm 2.7$ larvae in female mated with a single male, $83.4 \pm 6.5$ larvae in female mated with two males, $81.3 \pm 2.8$ larvae in female mated with three males, $79.2 \pm 6.2$ larvae in female mated with four males $89.5 \pm 6.3$ larvae in female with four males ( One-way Analysis of Variance $\mathrm{P}=0.6$ ) Table 1 .

Table-2: Fertility (hatchling rate \%)

\begin{tabular}{|l|l|l|l|l|}
\hline & Treatment & First clutch & Second clutch & third clutch \\
\hline \multirow{5}{*}{ Fertility (hatchling rate \%) } & Single mated & $90.2 \pm 2.6$ & $85.4 \pm 2.6$ & $80.2 \pm 2.7$ \\
\cline { 2 - 5 } & 2 Mated & $91.7 \pm 4.6$ & $92.6 \pm 4.5$ & $83.4 \pm 6.5$ \\
\cline { 2 - 5 } & 3 Mated & $88.6 \pm 5.2$ & $88.9 \pm 10.5$ & $81.3 \pm 2.8$ \\
\cline { 2 - 5 } & 4 Mated & $90.7 \pm 7.1$ & $87.8 \pm 8.1$ & $79.2 \pm 6.2$ \\
\cline { 2 - 5 } & Female\&4 males & $88.3 \pm 3.5$ & $89.3 \pm 4.8$ & $89.5 \pm 6.3$ \\
\hline One-way Analysis of Variance & $\mathrm{P}$ & 0.7830 & 0.7707 & 0.6089 \\
\hline
\end{tabular}

\section{Female's longevity}

Our results show a difference between the five treatments (With a log-Lank test, chi-square: $36.18 \mathrm{df}: 4$ P: 0.0056) (Fig.1). We found that single mated females survival is $62 \%$ in 40 days of observation while those mated with two males died, with a survival of $18 \%$ in 40 days. Mortality increase since 10 days with females mated with more than one male. There is no survival at 40 days in groups of females which remain with 4 males or mated with 4 males (Figure.1).

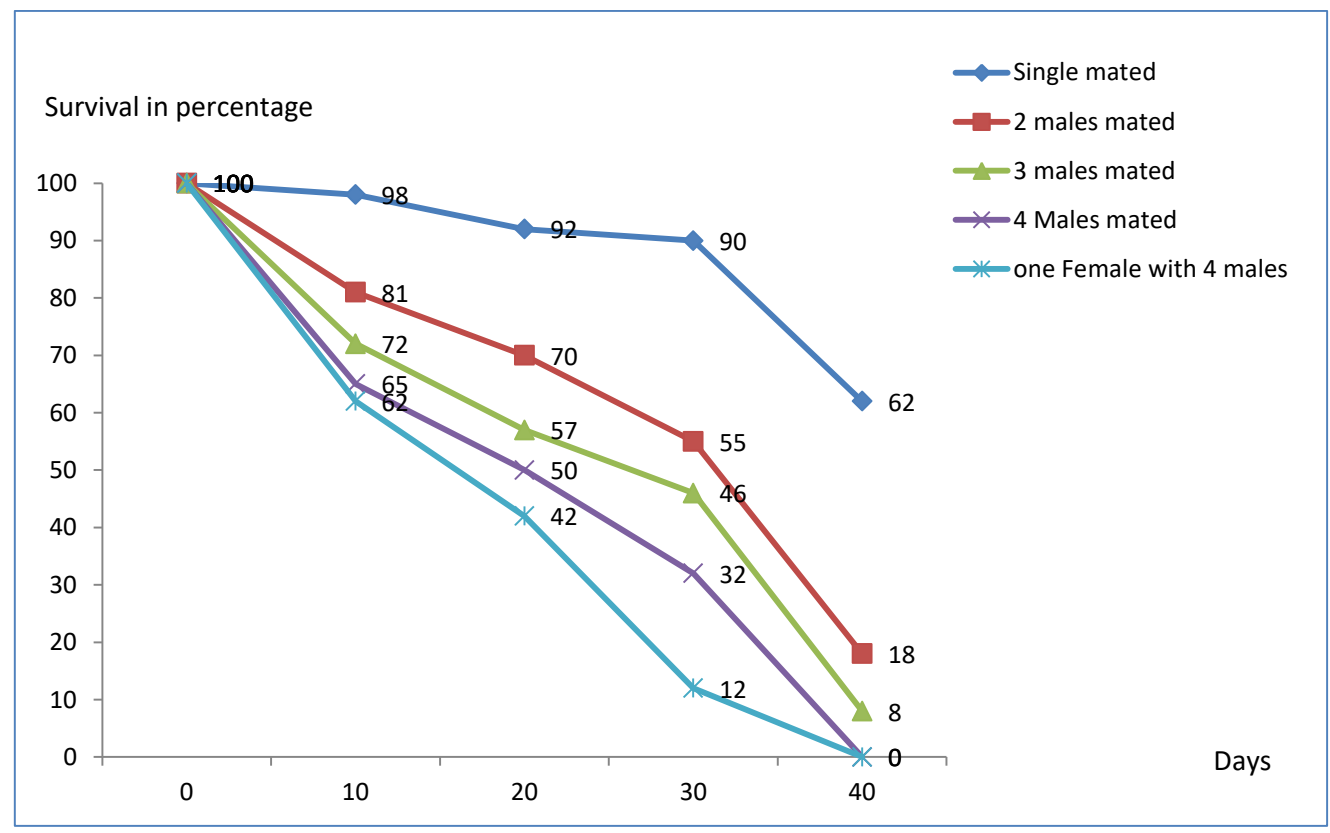

Fig-1: Survival of females after mating

\section{Offspring survival}

Our results show that survival of offspring from females mated with a single male is about 30 days and then begun to die. Mortality increase and only $74 \%$ of larvae reach at imago stage. The survival of offspring from females mated with two, three, four males remained higher and our results show that about $90 \%$ of larvae reach at imago stage (Figure 2). 


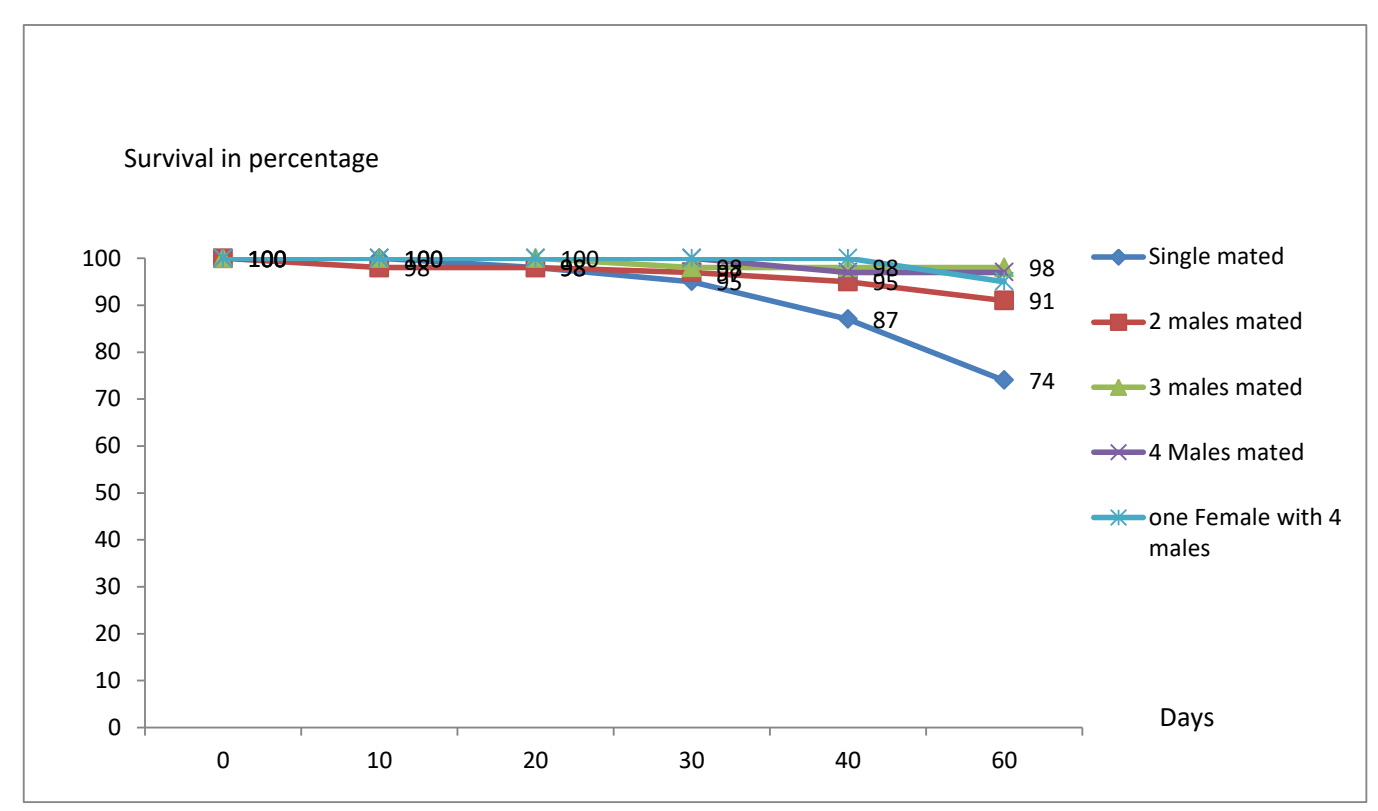

Fig-2: Offspring survival

\section{Discussion}

A better understanding the evolution of female desert locust multiple mating role is therefore key to understand locust phase polyphenism and locust outbreaks. The mechanism underlying the phase polyphenism in desert locust have been studied since many years and various aspects of this phenomenon has been clarified [24, 1, 25, 26, 27, 3, 28], but desert locust multiple mating have entail little attention in the reproduction strategies of this specie. Polyandry is known to be fitness successful strategies [29, 30, 31, 32]. In this paper, we experimentally varied the rate of copulation with different males in gregarious desert locust. We analysed female desert locust fecundity and fertility, females and offspring survival in order to understand the cost and benefice of desert locust multiple mating.

Our results suggest that multiple mating is not associated with fitness benefits. We have demonstrated that female desert locust fecundity and fertility is not affected by multiple copulation. We found that multiple mating affect female lifespan where we observed an increase in mortality in females mated with more than one male comparatively to females mated with a single male. Tetsuhiro et al. [33] have demonstrated that multiple mating reduces longevity of females, our results show that it is also the case in $S$. gregaria. We found that survival of offspring from females mated with two, three, four males remain higher and our results show that about $90 \%$ of larvae reach at imago stage while only $74 \%$ of larvae reach at imago stage in females mated with single male.

The sense of this result could be male-derived nutrients which are incorporated in female eggs thereafter in hatchlings as shown in other species [11,
$34,35]$. Our idea is sustained by the research on the function of egg yolk [36, 37].

Even though multiple mating in orthopteran species has been explained in terms of direct effect as to maximize fitness: fecundity and fertility enhancement, increase female lifespan and offspring survival [11, 38, $12,13,39,29,40]$, this study demonstrate that generalization cannot be made. Multiple mating has another explanation in S.gregaria. We found an increase of offspring survival from females mated with many males which survive longer than those from females mated with one male. We can conclude that multiple mating in $S$ gregaria acts as hormonal factor which controlling eggs contain which acted on offspring condition with a really impact on survival.

\section{REFERENCE}

1. Uvarov, B. (1966). Grasshopper and locusts. A handbook of general acridology, 1. Cambridge University Press.

2. CIRAD. (2004). Locusts: a threat to agriculture, a challenge for agronomic research. Crop protection programme. Prifas Operational Acridology; TA 40/D, Campus International de Baillarguet, 34398 Montpellier, cedex 5, France.

3. Pener, M.P., \& Smpson, J.S. (2009). Locust phase polyphenism:an apdate. Advances in insect physiology, 36:1-272

4. Simpson, S. J., Despland, E., Hägele, B. F., \& Dodgson, T. (2001). Gregarious behavior in desert locusts is evoked by touching their back legs. Proceedings of the National Academy of Sciences, 98(7), 3895-3897.

5. Dingle, H. (1995). Migration: the biology of live on the move ;Univ. Press, Oxford

6. Duranton, J.F., \& Lecoq, M. (1990). Le Criquet pèlerin au Sahel. Coll. Acridologie opérationnelle 
$\mathrm{n}^{\mathrm{o}}$ 6, CILSS-DFPV: Niamey/Ministère des Affaires Etrangères des Pays-Bas: La Haye /CIRADPRIFAS: Montpellier (France).183.

7. FAO. (2006). La lutte biologique contre le criquet pèlerin: nouvelles armes face à un ennemis ancestral. IPPC, Rome, Italy.

8. FAO. (2009). Rapport de la trente neuvième session du comité de lutte contre le criquet pèlerin de la FAO. Rome 44.

9. Lecoq, M. (2004). Vers une solution durable au problème du criquet pèlerin ? Sciences et

10. Reinhardt, K., \& Köhler, J. (1999). Costs and Benefits of Mating in the Grasshopper Chorthippus parallelus (Caelifera: Acrididae). Journal of Insect Behavior, 12(3), 283-293.

11. Friedel, T., Gillott, C. (1977). Contribution of male-produced proteins to vitellogenesis in Melanoplus sanguinipes. Journal of Insect Physiology, 23: 145-151.

12. Lange, A.B., Loughton, B.G. (1985). An oviposition-stimulating factor in the male accessory reproductive gland of the locust, Locusta migratoria. General and Comparative Endocrinology, 57: 208- 215.

13. Lafon-Cazal, M., Gallois, D., Lehouelleur, J., Bockaert, J. (1987). Stimulatory effects of male accessory-gland extracts on the myogenicity and the adenylate cyclase activity of the oviduct of Locusta migratoria. Journal of Insect Physiol-ogy, 33: 909-915.

14. Hinn, J. C., \& Niedzlek-Feaver, M. (2001). Spermatophore number transferred increases linearly with copulation duration in Melanoplus differentialis (Orthoptera: Acrididae). Journal of Orthoptera Research, 10(2), 147-152.

15. Voigt, C. C., Kretzschmar, A. S., Speakman, J. R., \& Lehmann, G. U. (2008). Female bushcrickets fuel their metabolism with male nuptial gifts. Biology letters, 4(5), 476-478.

16. Simpson, S. J., McCAFFERY, A. R., \& Hägele, B. F. (1999). A behavioural analysis of phase change in the desert locust. Biological reviews, 74(4), 461480.

17. Tanaka, S., \& Maeno, K. (2006). Phase-related body-color polyphenism in hatchlings of the desert locust, Schistocerca gregaria: re-examination of the maternal and crowding effects. Journal of insect physiology, 52(10), 1054-1061.

18. Tanaka, S., \& Maeno, K. (2008). Maternal effects on progeny body size and color in the desert locust, Schistocerca gregaria: examination of a current view. Journal of Insect Physiology, 54(3), 612-618.

19. Maeno, K., \& Tanaka, S. (2009). Artificial miniaturization causes eggs laid by crowd-reared (gregarious) desert locusts to produce green (solitarious) offspring in the desert locust, Schistocerca gregaria. Journal of insect physiology, 55(9), 849-854.

20. Highnam, K. C., \& Lusis, O. (1962). The influence of mature males on the neurosecretory control of ovarian development in the desert locust. Journal of Cell Science, 3(61), 73-83.

21. Highnam, K. C., \& Haskell, P. T. (1964). The endocrine systems of isolated and crowded Locusta and Schistocerca in relation to oöcyte growth, and the effects of flying upon maturation. Journal of Insect Physiology, 10(6), 849-864.

22. OKELO, O. (1979). Influence of male presence on clutch size in Schistocerca vaga Scudder (Orthoptera: Acrididae). International Journal of Invertebrate Reproduction, 1(5), 317-321.

23. Dushimirimana, S., Hance, T., \& Damiens, D. (2012). Comparison of reproductive traits of regular and irradiated male desert locust Schistocerca gregaria (Orthoptera: Acrididae): Evidence of last-male sperm precedence. Biology open, 1(3), 232-236.

24. Faure, J. C. (1932). The phases of locusts in South Africa. Bulletin of Entomological Research, 23(3), 293-405.

25. Dale, J. F. (1990). The endocrine basis of locust phase polymorphism. Biology of grasshoppers.

26. Pener, M. P. (1991). Locust phase polymorphism and its endocrine relations. Advances in insect physiology, 23, 1-79.

27. Pener, M. P., \& Yerushalmi, Y. (1998). The physiology of locust phase polymorphism: an update. Journal of Insect Physiology, 44(5-6), 365377.

28. Verlinden, H., Badisco, L., Marchal, E., Van Wielendaele, P., \& Broeck, J. V. (2009). Endocrinology of reproduction and phase transition in locusts. General and comparative endocrinology, 162(1), 79-92.

29. Symmons, P. (1988). A review of recent research on the desert locust relevant to its control and proposals for research and development work over about the next five years. In FAO Meeting on desert locust research, Rome, Appendix 21/VIII.

30. Madsen, T., Shine, R., Loman, J., \& Häkanson, T. (1992). Why do female adders copulate so frequently? Nature, 355:440-441.

31. Keller, L., \& Reeve, H. K. (1995). Why do females mate with multiple males? The sexually selected sperm hypothesis. Advances in the Study of Behaviour, 24, 291-316.

32. Zeh, D. W., \& Smith, R. L. (1985). Paternal investment by terrestrial arthropods. American Zoologist, 25(3), 785-805.

33. Kawagoe, T., Suzuki, N., \& Matsumoto, K. (2001). Multiple mating reduces longevity of females of the windmill butterfly Atrophaneura alcinous. Ecological Entomology, 26(3), 258-262.

34. Boggs, C. L., \& Gilbert, L. E. (1979). Male contribution to egg production in butterflies: evidence for transfer of nutrients at mating. Science, 206(4414), 83-84.

35. Boggs, C. L. (1990). A general model of the role of male-donated nutrients in female insects' 
reproduction. The American Naturalist, 136(5), 598-617.

36. Maeno, K., \& Tanaka, S. (2009). Artificial miniaturization causes eggs laid by crowd-reared (gregarious) desert locusts to produce green (solitarious) offspring in the desert locust, Schistocerca gregaria. Journal of insect physiology, 55(9), 849-854.

37. Tanaka, S., \& Maeno, K. (2010). A review of maternal and embryonic control of phasedependent progeny characteristics in the desert locust. Journal of insect physiology, 56(8), 911918.

38. Gwynne, D. T., Bowen, B. J., \& Codd, C. G. (1984). The function of the katydid spermatophore and its role in fecundity and insemination
(Orthoptera: Tettigoniidae). Australian Journal of Zoology, 32(1), 15-22.

39. Butlin, R. K., Woodhatch, C. W., \& Hewitt, G. M. (1987). Male spermatophore investment increases female fecundity in a grasshopper. Evolution, 41(1), 221-225.

40. Tregenza, T., \& Wedell, N. (1998). Benefits of multiple mates in the cricket Gryllus bimaculatus. Evolution, 52(6), 1726-1730.

41. Chapman, R. F., \& Joern, A. (Eds.). (1990). Biology of grasshoppers. John Wiley \& Sons.

42. Highnam, K. C. (1962). Neurosecretory control of ovarian development in Schistocerca gregaria. Journal of Cell Science, 3(61), 57-72.

Cite This Article: Dushimirimana Severin (2021). The Cost and Benefice of Multiple Mating in Desert Locust Schistocerca gregaria. East African Scholars J Agri Life Sci, 4(3), 49-54. 